\title{
Reconstruction of Accounting Education Purpose Concept through the Thoughts of Ki Hadjar Dewantara
}

\author{
Yohan Bachtiar $^{\mathrm{a}{ }^{*}}$, Dion Yanuarmawan ${ }^{\mathrm{a}}$, Iwan Triyuwono ${ }^{\mathrm{b}}$, Gugus Irianto ${ }^{\mathrm{b}}$ \\ ${ }^{a}$ Politeknik Kediri, Jalan Mayor Bismo 27 Kediri \\ ${ }^{\mathrm{b}}$ Universitas Brawijaya, J1. MT. Haryono Malang \\ 1yohan bakhtiar@yahoo.co.id \\ *corresponding author
}

ARTICLE INFO

\section{Article history}

Received 4 August 2019

Revised 10 October 2020

Accepted 30 October 2020

Keywords

Accounting education purpose;

Ki Hadjar Dewantara;

Accounting education concept

\section{ABSTRACT}

This study aims at exploring the fact in accounting education at college and formulating the concept of accounting education based on the thoughts of $\mathrm{Ki}$ Hadjar Dewantara, enveloped in his two books: education and culture. Ki Hadjar Dewantara's critical-spiritualistnationalist paradigm is used as a perspective to analyse the present accounting education. This study uses a qualitative approach and case studies as a research strategy. The substance (indicator) of spirituality value (Tauhid ontology and orderliness in physical and spiritual), moral value (the balance of Cipta-Rasa-Karsa or Tri-Sakti), enhanced degree of humanity, and independence values (freedom, independent and partiality to Indonesian people) were the method in this study. The result of this study shows that accounting education reality at economics faculty in the Real Learning University does not reflect the values of Ki Hadjar Dewantara's idealistic thinking. A formulation of accounting education purpose concept in universities must be established to produce a perfect human with pure spirituality through spiritual, moral and independence value. This concept also can be interpreted as a struggle to bring love in accounting education purpose concept.

This is an open access article under CC-BY-SA License

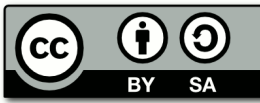

\section{Introduction}

The accounting and the accounting education are intertwined which stand as one body. Accounting is a branch of social science with all values to transform through the education for all the learners; therefore, it is a unity with the accounting education. Currently, the accounting for university students is focusing on the material in literature/modules, which is easy to understand and practice. That fact is appropriate with the students' situation, but there is also a need to address in relation with the values of accounting to balance the knowledge and substance of accounting itself.

This explanation is a result of self-reflection of learning about accounting in the past few years. Besides, I also learned and observed several kinds of research in the current accounting field that focus more on the mastery of the skill without paying attention to the importance of strong values of the accounting itself. As an example, during the National Accounting Symposium (SNA) in Mataram, there were some articles on the accounting field that merely focused on the effect on research variables instead of the strong values of accounting itself [1-3]. In relation with the educational philosophy, the sharing of the concept of values to the learners is an important element to shape their characters for the future [4]: 
"The concept of values is very important in education. The concept of education is to be visualised as nothing but a set of values in essence. Education is the transmission of what is worthwhile in those who become committed to it".

There are several critical kinds of research on the accounting area $[5,6]$ which confirm that there are values attached to conventional accounting. These values are capitalism, materialism, individualism, and secularism. These values have been embedded in accounting taught in university level. Accounting education is currently is in the prison of "beauty"; the masculinity, colonization, and relativity, hence requires a new point of view to shape an ideal accounting education [5].

It is common to see the current accounting education is closely related to the western values because Indonesia still refers its accounting education to the IES (International Education Standards) by the IFAC (International Federation of Accountants). Taking into account a broader look towards accounting education according to the IES, all of the current situation refers to the purpose of accounting education stated in the conceptual framework of IES:

"The goal of accounting education and practical experience is to produce competent professional accountants capable of making a positive contribution over their lifetimes to the profession and society in which they work" (IFAC Education Committee, 2003:27).

The purpose of accounting education based on the IES is to produce the competent and capable human resource as its final output. The emerging challenge now is whether or not those two aspects are adequate to equip the learners in facing professional life at work. When the two mentioned elements stand alone without other values; there is a possibility of fraud emergence in the professional accounting field.

There must be some questions about the correlation of this study with the thoughts of $\mathrm{Ki}$ Hadjar Dewantara. He was a national figure during the Indonesian Revolution whose focus was education. He was the founding father of the national study in Indonesia. There are many values from Ki Hadjar Dewantara thoughts that we can adopt to improve the education in Indonesia especially in the field of accounting. In his first book on education (1977) and the second book on culture (1967), Ki Hadjar Dewantara strongly criticized the western colonialists' educational values which are mostly against the Indonesian's local cultural values. His philosophies have become the analogical basic of thought to reconstruct the accounting education concept in Indonesia.

In relation with the KHD thoughts and their relevance with the current accounting education situation, this research has become the further study [7] of previously already stated the two elements mentioned before. KHD's thoughts based on his deep self-reflection on his two books has resulted in the basic concept of the reconstruction of accounting education in term of spirituality, courtesy, and freedom.

The reconstruction of accounting education purpose is the significant aspect of the education to direct the learners and facilitate them with all skills and knowledge to face their future in term of the professional field. The Indonesian accounting education purpose at the university level still focuses on the accounting skills and competence creates learners with characteristics of individualistic, intellectual, and materialistic characters.

Hence, there is a need to formulate a new concept on the accounting education purpose which is in line with the local values of Indonesia. This study has an aim to find out whether or not the purpose of accounting education in Indonesia is in accordance with the philosophies of Ki Hadjar Dewantara in term of Indonesian values of education. To address the problem this research aims at formulating the concept of accounting education based on the philosophies of Ki Hadjar Dewantara.

\section{Method}

Different to several existing paradigms in accounting [8], which are (1) Functionalist Paradigm, (2) Interpretivist Paradigm, (3) Radical Humanist Paradigm, and (4) Radical Structuralist Paradigm, this research is in the classification of critical-spiritualist-nationalist 
paradigm of Ki Hadjar Dewantara. The statement emerges of the great concern in the thoughts of Ki Hadjar Dewantara; his distinct viewpoint converts the basic concept in conducting this study. The spirituality, courtesy, and freedom of thought from KHD inspired the reconstruction concept of the accounting education purpose.

Figure 1. Conceptual Framework of the Research

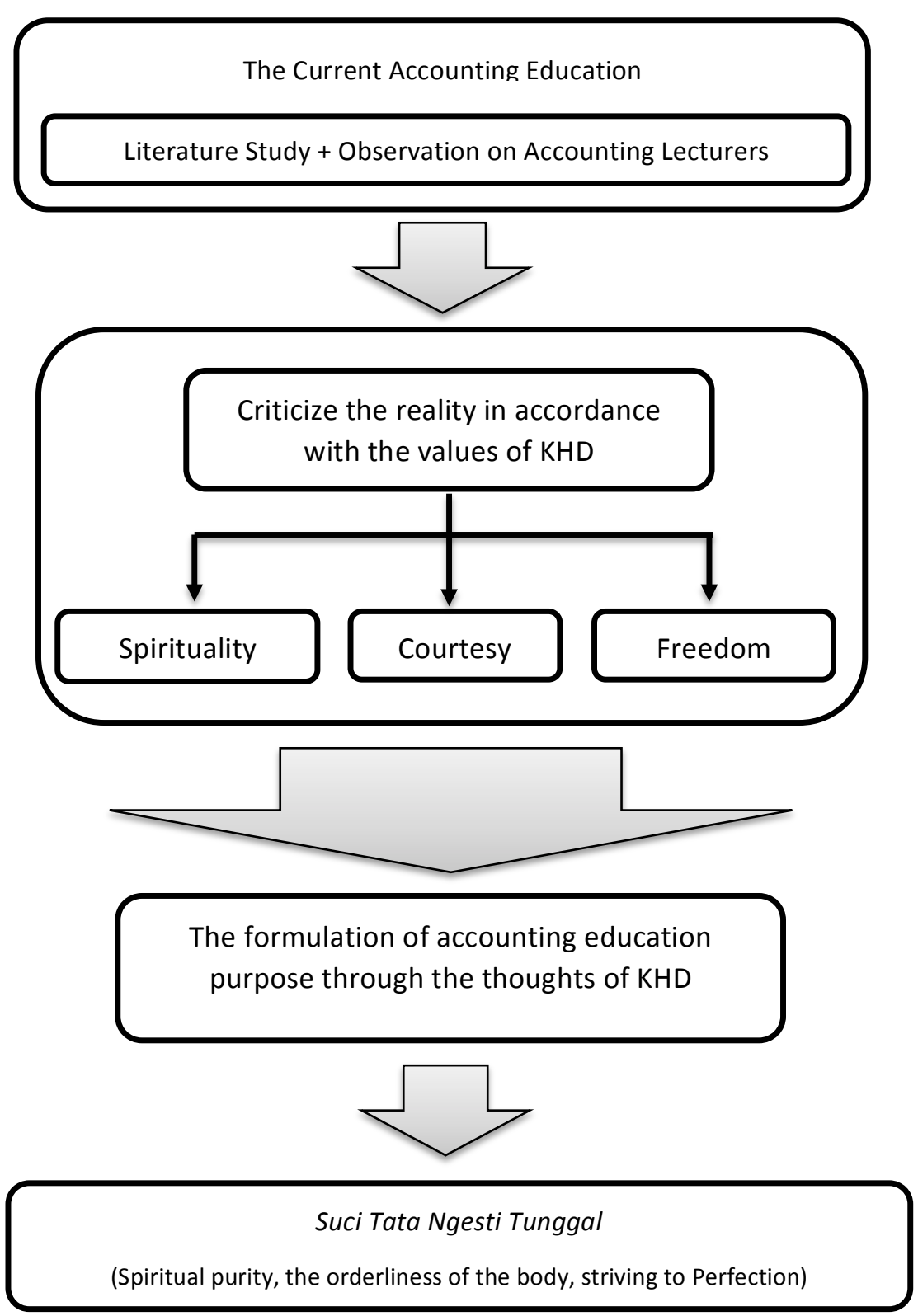

The step in formulating the research paradigm is a new concept in the accounting education field. The perspective of this research is in accordance with the beliefs of KHD which is proper with the current accounting education; the philosophies of which remain about western contents (intellectual, materialistic, egocentricity, and individualism) and the solution to exterminate the negative values by casting to the KHD's thoughts (spirituality, courtesy, and the freedom). This research uses a qualitative approach with case study as its strategy. This research uses the case study to address the question of how the accounting education concept matches the thoughts of $\mathrm{Ki}$ Hadjar Dewantara (KHD). The qualitative research that employes "how" question and whose purpose is to find out the current phenomenon requires the case study as one of its best strategies, as stated: 
"In general, case studies are the preferred strategy when "how" or "why" questions are being posed, when the investigator has little control over events, and the focus is on a contemporary phenomenon within some real-life context" [9].

The research method is the analytical tool to examine the social reality to reach the research's goal. This research focuses on the three substance of KHD's thoughts, resulted in the indicator emergence of spirituality (tawheed/monotheism to achieve the peaceful of mind and body), courtesy (the balance of create, sense, and intention /Tri-Sakti) to level up the humanity level, and the freedom (the freedom and independence provision towards the Indonesian people. Indicators of the three values are the basis of this research method.

The sites of this research were the study program of accounting, Faculty of Economic, at the Real Learning University. There are two types of objects in this research. Related informants were interviewed to gain a deeper insight on the use of Ki Hadjar Dewantara's values.

\section{Results and Discussion}

After a deep and intense discussion and interview on the reality of accounting education in relation with the spirituality, there is a conclusion that the spirituality is not an essential and fundamental value is the knowledge development (especially the accounting) at the current moment. There is a similar conclusion resulting from the lecturers and students on the negation between the accounting and spirituality values.

Another impact for not having a balance value of spirituality and materialism is money as students' mere orientation. If material objects can become the source of happiness, prosperity, and peace in life, it would mean that people consider money and other material objects as their main concern or as their God. The initial reason of materialism practice in the accounting education is because there is fundamental teaching to earn a maximum profit with the least cost. This economic principle has become a common practice.

Ki Hadjar Dewantara (KHD) did not explicitly direct his thought for the accounting education, instead he explained it for the general education context. His rejection of the western educational system (especially the embedded values of materialism) is however relevant with the current accounting education. As elucidated earlier, the current accounting perspective is to pursue material objects instead of the spiritual aspect. KHD's concern on western education system (including the science and knowledge) is as follows:

"...[present education] situation creates "intellectual dictator" which causes the emergence of two harmful characteristics of human, they are egoism and materialism which makes people concerned only about themselves and do not consider the needs of the spiritual aspect (religion, spirituality, and others)" [10]

KHD had warned his students to be critical especially towards the western educational system and knowledge. In accounting education, the egoistic and materialism occur due to the over-dominant influence of the mainstream accounting within the learners. The two characters have now been identified in the capitalism framework as the consequence of the development in the accounting education.

In relation with the accounting education purpose based on the spirituality, it is clear that the monotheism aspect must become the main concern to create an ideal accounting education that has a balanced outcome in term of physical and material aspects. When the conceptual framework does not include the monotheism, it is certain that during the learning process the emerging value will be secularism, both in its material and in the process itself. That has been precisely reflected in our current accounting education. The domination of the mainstream paradigm in capturing the reality of accounting is one of the factors that cause the smooth penetration of secularism in our academic field. This reality does not only occur in the field of accounting education but also in almost every education fields in Indonesia, at the university level. The secularism practice in the field of knowledge (accounting) is unacceptable based on Islamic rules as Islam believes in one God, Allah 
SWT, and Muhammad is His messenger. Ideally, the two life guidance must guide people to develop the accounting and accounting education.

Further, the spirituality of monotheism ontology is the solution for moral degradation due to the materialism practice among the accountant currently. They are more concerned about their life instead of eternal life after death. As an example, the basic concept of the economy to gain the maximum profit with the least cost is how the capitalists draw the Muslim to care only about money instead of other values. If there is an absence of tazkiyah ${ }^{1}$ in accounting education, there will be the collapse of Islamic civilization which consists of a full divinity.

As a logical consequence of the construction of the concept of accounting education goals in this study is the redefinition of accounting education goals in the frame of KHD spirituality values, namely the creation of perfect students with the growth and development of monotheistic values for the sake of physical and spiritual order. This is an attempt to present the values of Godliness in every process of accounting learning. There will be no more such thing as separation (secularization) between science (accounting) and the essence of Islam as a religion which is rahmatan lil amin alamin (blessings for all). This means that Islam is a religion that was revealed by Allah SWT as a mercy to the universe, including in accounting, accounting education, and other branches of science.

Thus, we as Muslim scholars should continue to fight for the values of Godliness, both in accounting and accounting education. If these noble ideals can be realized well, then human civilization that has physical and spiritual order, like what the KHD aspires to during the colonial era, will not be mere wishful thinking. This struggle will be interpreted as a way of worship so we draw closer to God. Accounting education has a great power in forming a civilization of science based on the values of spirituality.

\section{Concept Construction of Accounting Education Purpose in the Perspective of Courtesy Value of Ki Hadjar Dewantara}

In general, the reality of accounting education in higher education related to the value of character is still implemented implicitly and is limited to courses in business ethics and the profession. This shows the dichotomous way of thinking about the importance of ethical values that should be internalized in each subject that will be taught to students. Indeed, the internalization of the value of character should not be focused on certain subjects, but can also be exemplified by accounting educators as role models when . $\mathrm{n}$ the learning environment.

On the contrary, there is an intellectualism 'disorder' as stated by Ki Hadjar Dewantara below:

"We have come to an essential issue, the intellectualism, that can be shortly interpreted as 'the spirit of glorifying thoughts. This spirit seemed to eradicate courtesy, decreasing nobleness, promoting exasperation, and opposing and extirpating conscience of the true humanity". [10]

It would be such a noble thing if the accounting education can generate both the intellectuality and courtesy. This is aimed to provide students with a complex and holistic intelligence. If the intellectualism 'disorder' keeps developing in students, negative things as what stated below will occur:

"The decadence of spirituality, bravery, loyalty, generosity, and the willing to sacrifice of our people and the loss of humanity freedom, the lack of love among each other, or in short, the decadence of character among our descendants, are the consequences of intellectualism" [10]

Of course, these are long-term consequences of ignoring the moral values in accounting education. Ki Hadjar Dewantara stated that the decadence of moral values in humans results in the lack of love among them. Therefore, it is the time to embed character education in accounting since

1 Tazkiyah in accounting knowledge context (especially for sharia accounting) was developed by Mulawarman [15] 
accounting is the product of thoughts by the moral and civilized humankind. He provided the guidelines for building good attitude and character of students through education and thus generating the spirit of tri-sakti, comprising thought, feeling, and will. These three should be equally possessed by the students for the sake of security and prosperity. This idealism aimed to encourage those who involve in education to dignify their humanity. Hence, what we learn from the learning process and what we do in our daily lives will be the reflection of the beauty of the character of ourselves. That is the essence of character learning. Indeed, this is the dream of Ki Hadjar Dewantara.

It is reasonable when the construction of the concept of accounting education objectives generates a definition. Therefore, the objective of accounting education based on the character value proposed by Ki Hadjar Dewantara is to generate humankind with the good character based on the spirit of tri-sakti and thus dignify humanity. This will lead to the implementation of the moral values among students in their working world and daily lives. Therefore, the internalisation of moral values in the concept of accounting education objectives in Indonesia is crucial. It means that we need guidelines and originality in building the character of the students without directly following the international standard of accounting education. We have to adjust the system to our culture and noble ideas. A great, independent, just, and prosperous nation is built by civilized individuals.

\section{The Construction of the Accounting Education Concept Purpose in the Perspective of Independent Value by Ki Hadjar Dewantara}

Generally, accounting education is implemented under foreign hegemony, since as the member of IFAC, Indonesia should obey the Statement of Membership Obligation. Consequently, Indonesia should adopt the IES (International Accounting Standards) comprising the Indonesian Accounting Education Standard (SPAI) drafts that are currently under completion by the IAI-KAPd (Indonesian Accountant Association-Compartment of Accounting Educators). As an independent country, Indonesia should have been able to create its own standard without intervention from foreign party.

Another form of hegemony is the market orientation. The outputs of the learning process of accounting education in universities in Indonesia are targeted to accommodate the market interest. The market indeed has a great power to control the accounting education [11]. This, of course, is against the Indonesian noble ideas and characteristics. All matters, including education, should prioritise Indonesian people.

A sovereign nation is a free and independent one in all aspects. The sovereignty of Indonesia comprises noble ideals that support the interest and prosperity of the people. It means that wherever the national policy points at (in this case, the accounting education system), people's interest should come first. Therefore, we should initiate a wave of struggle to gain freedom and independence in implementing the accounting education. Starting from this thought, we should be able to formulate the SPAI that corresponds to our cultural values. The critical thinking of Ki Hadjar Dewantara regarding the independence values that is reflected by freedom, independence, and populism is a part of the concept of accounting education objectives in universities. This aims to generate accounting students that are not only competent, but also have characteristic, freedom, independence, and populism and to prevent them from making a harmful decision in their future jobs.

As a responsible institution in making the SPAI drafts, IAI-KAPd should prioritise the internalisation of the noble values: freedom, independence, and populism to overcome the dependence on the foreign policy. Since accounting is a part of politic interest, the foreign party will try to homogenise the international policies by formulating standards that should be followed by the member countries. If we still believe in our existence as a great and dignified nation, we should be able to create our own populist standards. It requires energies and thoughts of all practitioners and academicians to formulate a nationalist standard of accounting education.

From the explanations and arguments above, the logical consequence of the formulation of the concept of accounting education objectives based on the independence value by Ki Hadjar Dewantara is the realisation of the concept definition of accounting education objectives, which is 
to generate the free, independent, and populist human. This obviously will result in the increasing sense of nationalism among the youth of today in defending their country.

\title{
The Reconstruction of the Concept of Accounting Education Purposes in Ki Hadjar Dewantara's Perspective: A Struggle for Evoking Love
}

\author{
Imagine $^{2}$ \\ (with apologies to John Lennon) \\ Imagine (3) \\ accountants \\ only think \\ to enhance disclosures \\ those that rarely have been read \\ never question \\ the fundamental natures \\ the forms and substances \\ the main testimony \\ they produce, \\ reproduce, \\ and preach \\ to legitimate and justify \\ actions and reactions \\ Imagine (4) \\ accountants \\ 'unsighted' \\ to morality and ethics \\ to justice, fairness, and equity \\ to humanity
}

We intentionally quoted a poem [12] to describe a general reality of the accounting profession that more prioritise competence and rationality than the essence and substance of the discipline. Moreover, the lack of moral values in accounting education leads to frauds and violations of accounting code of ethics.

After deep contemplation, we found that love is the essence that must exist in the concept of accounting education purposes. Love is the substance of Tauhid ontology as an effort to gain physical and spiritual balance, searching for the essence of character values as the realisation of the balance of the spirit of tri-sakti for dignifying humanity, and interpreting the value of sovereignty as the struggle for freedom, independence, and populism were the efforts of evoking love in in the concept of accounting education purposes.

For further details, the first essence of love is spiritual value. Obviously, with the Tauhid ontology as the main value, the accounting education becomes the realisation of love towards Allah SWT. It means that education becomes the medium to get closer to Him. Then, I referred to Al Qur'an regarding the importance of learning. The interpretation of Surah Al-Alaq verse 1: Iqra' bismi Rabbik" is "Live your whole life and existence for Allah". This is the essence of the Tauhid (monotheism), especially in education. Therefore, evoking love in accounting education becomes a worship substance for developing a discipline. Next, love should be reflected through character. By possessing a noble characteristic, the devotion upon noble values will arise. The union of thought, feeling, and will as trisakti spirit will dignify humanity among students. If the value has been internalised in the concept of accounting education purposes, noble characters would be possessed by those who are involved in the education. The third essence is realised through

\footnotetext{
2 This poem entitled "Imagine' actually comprises five substances. However, I only quoted "Imagine (3)" and "Imagine (4)" since they are relevant to the research's context.
} 
sovereign value. This value is generated by nationalism. If it is internalised in the concept, the students will gain freedom, independence, and populism during the learning process.

For the reference and justification on the presence of love in accounting education, I found several articles about the essence of love in accounting. Kamayanti (2012: 16) stated that the love to God that manifests in form of the devotion to justice and sovereignty liberates oneself from all kinds of colonialism. This made me realise that devotion to God (mahabbah) is an energy of liberating oneself from all kinds of colonialism. Moreover, Mulawarman (2008: 149) defined 'hyper love' as a complete understanding of educational interaction that is based on trust and honesty and dispels prejudice and betrayal. Regarding the relationship between accounting education and faith, it is stated that:

"Religious love and moral are the main foundation of accounting education. Religiosity ends on faith. In fact, the core of faith is love". [13]

Indeed, the essence of love is the faith of a human to Allah SWT. If the concept of accounting education objectives is fulfilled by love as the manifestation of love towards the Almighty Love, then all the elements of it will become an absolute and eternal love, that is the love to Allah SWT. Thus, the effort of evoking love in the concept is a person's manifestation of faith to his God. In accounting, love becomes a fundamental value that is potential to eliminate the negative values of conventional accounting:

"The destruction caused by accounting basically can be eliminated by implementing the value of love. Love is a God's characteristic that brings peace".[14]

\section{Realising the Sacred Civilisation of Tata Ngesti Tunggal (Spiritual Purity, Physical Discipline, Reaching Perfection)}

Since Ki Hadjar Dewantara did not provide a detail explanation of the slogan Tata Ngesti Tunggal, we tried to interpret it according to the context of this research. When the accounting education in Indonesia is open for foreign regulation and policies, the students are prone to losing their identity as monotheistic, free, independent, noble Indonesians. As the manifestation of the character of national struggle in rejecting all kinds of colonialism, Ki Hadjar Dewantara demanded a national order where the people are spiritually and physically disciplined for a perfect civilisation that based on devotion to God Almighty. Related to the noble ideals, accounting education should be a means of achieving the perfection of life. There is no more injustice, personal despotism, oppression, or colonialism in accounting education. Only peace, beauty, nobleness, and devotion to God remain.

For his noble visions, Ki Hadjar Dewantara deserves to be our paragon. His struggle in realising a civilised nation of Indonesia should be carried on. Hence, in the context of this research, we tried to formulate a general concept of accounting education objectives based on his values as follows: "Generating the perfect human beings by purifying their spirituality and disciplining their physical aspects through the spiritual, characteristic, and independence values".

A whole love is the realisation of love to Allah SWT, to a noble life, and to the country. Hence, love is a logical consequence of the realisation of the ideal accounting education objectives in the perspective of Ki Hadjar Dewantara and is an essential and fundamental value to be internalised among students. On this matter:

"The consciousness (èling) will be achieved when there are unions of thought-feelingwill, ethics-mora-spirituality, and understanding-considering-executing. It will bring us to the spirituality since it is a power of motivation to see within ourselves and an intuition that a person should change him/herself especially when it is related to spiritual life".[6]

Love is based on the consciousness (èling) on the meaning of human creation as khalifatullah fil'ardh, the representative of God on earth that holds the task to worship God and to spread the value of kindness for the universe. These are the manifestation of a person's faith in his/her God. Therefore, the accounting education objectives that are based on the essence of love i.e. faith and 
divine consciousness will generate educators and students that will reflect love and consciousness in their daily lives. Hence, an accounting education that spreads the seeds of love and divine consciousness for the development of noble and justice civilisation will no longer be a dream.

\section{Conclusion}

Generally, the reality linkage between accounting education and the three values of Ki Hadjar Dewantara (spirituality, character, and independence) have not properly internalised yet in universities. If it is ignored for a long time, the students will be corrupted by negative values of conventional accounting. This proves that the reconstruction of the concept of accounting education purposes is highly demanded to neutralize the possible effects.

The reconstruction results lead to a point of contact in which the point is a reflection of the values of spirituality, character, and independence. We interpret the points as a struggle in evoking love in the concept of accounting education objectives. The essence of love is faith. Hence, if the concept of accounting education objectives is filled with love, then the process of accounting education is the manifestation of love to Allah SWT. The formulation of the concept of accounting education objectives is "Generating the perfect human beings by purifying their spirituality and disciplining their physical aspects through the spiritual, characteristic, and independence values".

\section{References}

[1] Bachtiar E, Fitriyani V, Anggraita, Rais KA. Analisis Peranan Kurikulum dan Lingkungan Akademik terhadap Tingkat Pemahaman dan Kepekaan Mahasiswa terhadap Korupsi dan Tindakan Tidak Beretika dalam Bisnis. Simp. Nas. Akunt. 17, Mataram: 2014.

[2] Afdal, Hasanuddin MR. Pengaruh Komitmen Profesional dan Sosialisasi Antisipatif terhadap Sikap Mahasiswa Akuntansi atas Akuntabilitas Sosial Perusahaan. Simp. Nas. Akunt. 17, Mataram: 2014.

[3] Ngadiman, Muchlish M, Bangun N. Prinsip Pengendalian, Ambiguitas Peran, dan Kinerja Karyawan serta Keinginan Berpindah Kerja (Studi Empiris pada Profesi Dosen di DKI Jakarta). Simp. Nas. Akunt. 17, Mataram: 2014.

[4] Bharathi V, Rao BD. Educational Philosophy of Swami Vivekananda. New Delhi: Discovery Publishing House; 2005.

[5] Kamayanti A. Liberating Accounting Education: through Beauty and Beyond. Germany: Lambert; 2012.

[6] Ekasari K. Rehumanisasi Pendidikan Akuntansi Melalui Pendekatan Epistemologi 3Ling. J Akunt Multiparadigma 2014;5:273-86.

[7] Bakhtiar Y, Triyuwono I, Irianto G. The Values of Ki Hadjar Dewantara's Critical Education: Fundamental Concept of Accounting Education Objective. Int $\mathrm{J}$ Account Bus Soc $2015 ; 23$.

[8] Burrell G, Morgan G. Sociological Paradigms and Organisational Analysis: Elements of the Sociology of Corporate Life. Great Britain: Arena; 1979.

[9] Yin R. Case Study Research: Design and Methods (Second Edition). Thousand Oaks, California: Sage Publications Inc.; 1994.

[10] Soerjaningrat S. Karya Ki Hajar Dewantara Bagian Pertama: Pendidikan. Yogyakarta: Majelis Luhur Persatuan Taman Siswa; 1977.

[11] Triyuwono I. "Mata Ketiga": Se Laen, Sang Pembebas Sistem Pendidikan Tinggi Akuntansi. J Akunt Multiparadigma 2010;1:1-23.

[12] Irianto G, Gaffikin M. Imagine (with apologies to John Lennon). Crit Perspect Account 2006;17:140-1. doi:10.1016/j.cpa.2004.10.008.

[13] Mulawarman AD. Pendidikan Akuntansi Berbasis Cinta: Lepas dari Hegemoni Korporasi Menuju Pendidikan yang Memberdayakan dan Konsepsi Pembelajaran yang Melampaui. EKUITAS (Jurnal Ekon Dan Keuangan) 2008;12:142-58. doi:10.24034/j25485024.y2008.v12.i2.2066.

[14] Triyuwono I. Akuntansi Syariah: Perspektif, Metodologi, dan Teori. Third. Jakarta: PT. Raja Grafindo Persada; 2012.

[15] Mulawarman AD. Menyibak Akuntansi Syariah. Yogyakarta: Kreasi Wacana; 2006. 